\title{
Epidemiologi på nye måter
}

Hensikten med epidemiologiske studier er å finne årsaker til sykdom - for så å etablere en vitenskapelig basis for forebygging. Faget er pluralistisk og pragmatisk. Som andre empiriske vitenskaper er epidemiologien avhengig av tankemodeller som prøves ut mot faktiske observasjoner. Fortolkning av funnene står sentralt. Kan sammenhengene mellom eksponeringer og sykdom fortolkes som årsakssammenhenger og dermed komme til nytte i praktisk folkehelsearbeid?

Epidemiologer er som regel forsiktige med å slå fast at man har funnet en årsakssammenheng. Et hovedproblem er konfundering, det at det kan være en annen faktor assosiert med den aktuelle eksponeringen man ser på som er årsak til sykdommen som studeres. I et tilstrekkelig stort randomisert, kontrollert forsøk er konfundering langt på vei eliminert, fordi konfunderende faktorer fordeles likt $\mathrm{i}$ intervensjons- og kontrollgruppene. Men randomiserte forsøk kan oftest ikke benyttes når man skal vurdere konsekvensene av miljøgifter eller levekår, fordi disse eksponeringene ikke enkelt lar seg manipulere eksperimentelt eller fordi det ville være uetisk å gjennomføre eksperimenter.

Flere forskningsdesigner er foreslått for å løse problemet med konfundering. En slik design er bruk av instrumentvariabelanalyse (1). I medisinen kan instrumentet være en variabel som er assosiert med eksponeringen man er opptatt av, men ikke med sykdommen på annen måte enn gjennom eksponeringen. Hvis man ikke finner sammenheng mellom instrumentvariabelen og utfallet, svekkes hypotesen om at eksponeringen er en årsak. En spesiell form for bruk av instrumentvariabler kalles mendelsk randomisering (2). Det innebærer bruk av gener som kan påvirke nivået av en eksponering, men som ikke har sammenheng med variabler som kan konfundere relasjonen mellom eksponering og effekt. Én viktig forutsetning er altså at genet ikke påvirker sykdommen gjennom en helt annen mekanisme (3). Mendelsk randomisering presenteres i dette nummer av Tidsskriftet (4). Denne metoden blir mer og mer brukt i epidemiologien fordi det stadig blir påvist nye gener som er assosiert med eksponeringer.

Andre metoder for å begrense problemet med konfundering forutsetter ikke molekylærgenetiske undersøkelser. Dette gjelder for eksempel bruk av kontrasteksponeringer. I en unders $ø$ kelse fra den norske mor-og-barn-undersøkelsen (MoBa) (5) er det vist at kvinner som tok tilskudd av folat rett før og etter at de ble gravide, hadde lavere risiko for at barnet utviklet autisme (6). Som kontrasteksponering undersøkte man om inntak av tran hadde samme effekt. Man kunne tenke seg at de som brukte vitaminer generelt hadde et levesett som medførte lavere risiko for å få barn med autisme, uten at det var vitaminene i seg selv som var virksomme. At man fant en sammenheng mellom folat og autisme, men ikke mellom tran og autisme, styrker hypotesen om en årsakssammenheng mellom folat og denne utviklingsforstyrrelsen.

Et lignende eksempel er å se på fars levevaner når man skal vurdere effekten av mors levevaner på fosterets helse (7). Mors røyking reduserer barnets fødselsvekt. Hvis dette ikke skyldtes in uteroeffekten av røyking, men at røykingen hang sammen med andre forhold i familiemiljøet som påvirket fosterets vekst, ville en kontrast være å se på sammenhengen mellom fars røykevaner og barnets fødselsvekt. Kontrollert for mors røyking finner man imidlertid svært liten effekt av fars røyking på barnets fødselsvekt.

I MoBa-undersøkelsen har man også brukt diskordant søskenanalyse (8). Her sammenliknet man søsken der mor hadde brukt paracetamol ofte i ett svangerskap, men ikke i et annet. Når man sammenlikner søsken i stedet for tilfeldige barn, har man kontrollert for en rekke mulige konfunderende faktorer, fordi søsken har felles bakgrunn. Barnet som hadde vært eksponert for paracetamol, var i gjennomsnitt oftere forsinket psykomotorisk enn barnet som ikke hadde vært eksponert, noe som støtter hypotesen om en årsakssammenheng mellom bruk av paracetamol og psykomotorisk utvikling.

Før man aksepterer at en gitt eksponering forårsaker sykdom, bør klare statistiske sammenhenger, justert for konfunderende faktorer, være påvist i flere undersøkelser, gjerne med ulik design, og helst i flere populasjoner. Hvis kontrollerte forebyggende forsøk kan gjennomføres, er det selvfølgelig ønskelig. Men når dette ikke er mulig, kan man komme langt dersom man utnytter alle mulighetene som ligger i epidemiologiske designer.

\section{Per Magnus}

per.magnus@fhi.no

Per Magnus (f. 1951) er dr.med. og spesialist i medisinsk genetikk. Han arbeider med befolkningsundersøkelser og er fagdirektør ved Folkehelseinstituttet og professor II ved Universitetet i Oslo.

Forfatter har fylt ut ICMJE-skjemaet og oppgir ingen interessekonflikter.

\section{Litteratur}

1. Angrist JD, Krueger AB. Instrumental variables and the search for identification: from supply and demand to natural experiments. J Econ Perspect 2001; 15: $69-85$.

2. Smith GD, Ebrahim S. 'Mendelian randomisation': can genetic epidemiology contribute to understanding environmental determinants of disease? Int J Epidemiol 2003; 123: 15-33.

3. Burgess S, Timpson NJ, Ebrahim S et al. Mendelian randomization: where are we now and where are we going? Int J Epidemiol 2015; 44: 379-88.

4. Stensrud M. Mendelsk randomisering - genetisk tilnærming til epidemiologisk metode. Tidsskr Nor Legeforen 2016; 136: 1002-5.

5. Magnus P, Birke C, Vejrup K et al. Cohort Profile Update: The Norwegian Mother and Child Cohort Study (MoBa). Int J Epidemiol 2016; 45: 382-8.

6. Surén $\mathrm{P}$, Roth $\mathrm{C}$, Bresnahan $\mathrm{M}$ et al. Association between maternal use of folic acid supplements and risk of autism spectrum disorders in children. JAMA 2013; 309: 570-7.

7. Smith GD. Assessing intrauterine influences on offspring health outcomes: can epidemiological studies yield robust findings? Basic Clin Pharmacol Toxicol 2008; 102: 245-56.

8. Brandlistuen RE, Ystrøm E, Nulman I et al. Prenatal paracetamol exposure and child neurodevelopment: a sibling-controlled cohort study. Int J Epidemiol 2013; 42: 1702-13 